\title{
KECEMASAN MAHASISWA DALAM MENGHADAPI SEMINAR HASIL SKRIPSI DI LINGKUNGAN FKIP UNIVERSITAS MUHAMMADIYAH PALEMBANG
}

\author{
Muhammad Habibullah ${ }^{1}$ \\ Yetty Hastiana ${ }^{2}$ \\ Saleh Hidayat ${ }^{3}$ \\ ${ }^{1,2,3)}$ Program Pascassarjana Pendidikan Biologi FKIP Universitas Muhammadiyah \\ Pale mbang \\ Email: habibullah.ump@gmail
}

\begin{abstract}
In everyday life, someone must have experienced anxiety. Anxiety is a natural thing that has been experienced by every human being. Some of the final semester students, think of the thesis as something scary and a heavy burden and a barrier to graduation (becoming a graduate). In this phase, it is usually a stressful situation among students. Such an assumption causes students to be anxious when they have to face a thesis result seminar. This study aims to determine the level of anxiety of students in facing the thesis seminar in the FKIP Muhammadiyah University Palembang. The research method used is a qualitative research method. Data collection techniques using questionnaires (questionnaires) and interviews. In this study, the population was 18 students with a purposive sampling technique. The variable in this study is student anxiety. Based on the results of research data analysis, it can be concluded that students who do not have anxiety with a percentage of $22.22 \%$, students who have moderate anxiety levels with a percentage of $66.66 \%$ and students who have severe anxiety levels with a percentage of $11.12 \%$. Factors that affect student anxiety in facing the thesis seminar, namely: self-confidence, age, gender, understanding of the contents of the thesis, interaction relations examiners and supervisors, social support, ability to communicate, and mindset.
\end{abstract}

Kata Kunci: kecemasan mahasis wa, seminar hasil skripsi.

\section{PENDAHULUAN}

Sebelum menyelesaikan proses pembelajaran di Fakultas Keguruan dan Ilmu Pendidikan (FKIP) Universitas Muhammadiyah Palembang, seluruh mahasiswa semester akhir wajib untuk menyusun suatu karya ilmiah yang disebut Skripsi.

Menurut Darmono \& Hasan (2005), bahwa skripsi merupakan hasil karya ilmiah yang ditulis oleh mahasiswa program sarjana pada akhir masa studinya berdasarkan hasil penelitian, atau pengembangan terhadap suatu masalah atau kajian kepustakaan. Mahasiswa semester akhir, dituntut untuk menyelesaikan skripsinya yang harus memiliki kemampuan dalam mengindentifikasi dan merumuskan permasalahan, menyusun rencana penelitian, melaksanakan penelitian, pengamatan, pengolahan dan analisa data, serta menyusun hasil penelitian dan melaporkannya. 
Skripsi merupakan kerja ilmiah tertulis yang dibuat mahasiswa sebagai laporan tugas akhir. Ada beberapa tahapan yang harus dilalui mahasiswa pada saat proses menyusun skripsi, salah satunya seminar hasil skirpsi. Seminar hasil skripsi bertujuan untuk memberikan kemampuan kepada mahasiswa menyampaikan mulai dari latar belakang, rumusan masalah, tujuan, rancangan penelitian sampai hasil penelitian yang telah dilakukannya, baik secara tertulis maupun secara lisan.

Dalam kehidupan sehari-hari, seseorang pasti pernah mengalami kecemasan. Kecemasan merupakan hal yang alamiah yang pernah dialami oleh setiap manusia dan sudah dianggap sebagai bagian dari kehidupan sehari-hari. Sebagian mahasiswa, mungkin skripsi dianggap sebagai momok yang menakutkan dan beban berat serta penghambat kelulusan (menjadi sarjana). Pada fase ini, biasanya menjadi stress tersendiri dikalangan mahasiswa. Anggapan demikian menyebabkan mahasiswa menjadi cemas ketika harus menghadapi Seminar Hasil skripsi (Rachmat, 2009). Hal ini sejalan dengan penelitian yang telah dilakukan oleh Linayaningsih (2007), yang berjudul "kecemasan pada mahasiswa fakultas psikologi Universitas Katolik Soegijapranata dalam mengerjakan.

Cemas merupakan suatu hal yang sering terjadi dalam hidup manusia. Kecemasan timbul akibat adanya respon atau konflik. Hal ini biasa terjadi pada saat seseorang mengalami perubahan situasi dalam hidupnya dan dituntut untuk mampu beradaptasi (Rachmat, 2009). Kecemasan juga dapat terjadi akibat pengalaman baru yang belum pernah dialami sebelumnya. Demikian pula permasalahan yang muncul ketika seseorang mahasiswa menghadapi Seminar Hasil skripsi, mahasiswa merasa cemas karena menganggap Seminar Hasil skripsi merupakan hal yang baru atau pengalaman yang baru (Linayaningsih, 2007).

Jika dilihat dari fenomena yang telah diulas sebelumnya, dapat diketahui bahwa mahasiswa mengalami kecemasan disebabkan oleh skripsi. Oleh karena itu, kecemasan yang dialami oleh mahasiswa tersebut termasuk ke dalam academic anxiety (kecemasan akademik). Menurut Ottens (1991), kecemasan akademik mengacu pada pola yang mengganggu pikiran, respon fisiologis dan perilaku yang mengikuti dari kekhawatiran tentang kemungkinan kinerja yang sangat buruk pada tugas akademik. Salah satu bentuk dari tugas akademik itu adalah mengerjakan skripsi. Kecemasan ini terjadi karena mahasiswa belum pernah mengalami hal tersebut, seperti bimbingan dengan dosen, seminar dengan beberapa orang dosen di dalam ruangan, serta adanya pengaruh akan cerita-cerita mengenai skripsi yang didapatkannya dari senior dan temanteman mereka. Hal ini menyebabkan mahasiswa memiliki pikiran-pikiran yang akan membentuk perilakunya. Pikiran tersebut berupa kepercayaan atau keyakinan seseorang tentang ketakutan serta kekhawatiran yang dirasakannya, yang mana sumber ketakutan tersebut menjadi penyebab timbulnya kecemasan. Mahasiswa 
yang tidak mampu menghadapinya akan cenderung untuk menghindar. Jika mahasiswa terus menghindar, maka dampaknya adalah skripsi mahasiswa tersebut akan lebih lama selesai karena tidak dikerjakan.

Menurut Hawari (2006), menjelaskan bahwa faktor yang mempengaruhi kecemasan tergantung pada struktur perkembangan kepribadian diri seseorang yaitu usia, jenis kelamin, tingkat pendidikan, dukungan sosial dari keluarga, teman dan masyarakat. Sedangkan menurut Djiwandono (2005), ada beberapa faktor yang mempengaruhi kecemasan yakni kepercayaan diri, dukungan sosial dan modeling.

Dalam penyelesaikan tugas skripsi mahasiswa mengalami banyak permasalahan sehingga kecemasan dan tingkat stres juga akan meningkat. Terdapat 2 faktor penyebab stres dalam menyusun skripsi yaitu faktor internal dan faktor eksternal. Faktor internalnya yaitu sikap malas mahasiswa yang hanya mengerjakan skripsi jika ada keinginan dan banyak dari mahasiswa yang tidak percaya dengan kemampuannya. Faktor eksternal antara lain kesulitan mencari judul, kesulitan mencari literatur dan dana terbatas, bahan bacaan, atau takut menemui dosen pembimbing.

Hal di atas merupakan salah satu dampak dari kecemasan, seperti yang diungkapkan oleh Nevid (2005). Salah satu ciri dari kecemasan ini adalah adanya perilaku menghindar. Bagi mahasiswa yang sedang mengerjakan skripsi, perilaku menghindar itu berupa menunda-nunda mengerjakan skripsinya. Fenomena menunda mengerjakan skripsi juga ditemukan pada hasil wawancara. Alasan mereka menunda itu adalah untuk mencari kesenangan dan menghilangkan kejenuhan dalam mengerjakan skripsi.

Berdasarkan latar belakang diatas, peneliti tertarik untuk mengadakan penelitian dengan judul 'Kecemasan Mahasiswa dalam Menghadapi Seminar Hasil Skripsi di Lingkungan FKIP Universitas Muhammadiyah Palembang”.

\section{METODE}

Metode yang digunakan dalam penelitian ini adalah metode penelitian kualitatif. Teknik yang digunakan dalam pengambilan sampel adalah Purposive Sampling, karena peneliti melihat adanya perbedaan pada masing-masing mahasiswa. Mahasiswa yang dijadikan objek dalam penelitian berdasarkan teknik Purposive Sampling, yaitu: 18 orang mahasiswa yang akan menghadapi seminar hasil skripsi.

Penelitian ini akan dilaksanakan di Lingkungan FKIP Universitas Muhammadiyah Palembang, pada bulan Agustus 2018 Tahun Ajaran 2017/2018 pada Periode Semester Genap. Waktu penelitian disesuaikan berdasarkan daftar mahasiswa Program Studi Pendidikan Biologi FKIP Universitas Muhammadiyah Palembang yang akan melaksanakan Seminar Hasil Skripsi. 
M. HABIBULLAH, Y. HASTIANA \& S. HIDAYAT, KECEMASAN....

\section{HASIL DAN PEMBAHASAN}

Tabel 1. Data Hasil Analisis Angket (Kuesioner) Tingkat Kecemasan Mahasiswa

\begin{tabular}{ccccc}
\hline No. & Nilai & $\begin{array}{l}\text { Jumlah } \\
\text { Mahasis wa }\end{array}$ & Keterangan & \multicolumn{2}{c}{$\begin{array}{l}\text { Persentase } \\
(\boldsymbol{\%})\end{array}$} \\
\hline 1. & $20-44$ & 4 & Tidak cemas & $22 \%$ \\
2. & $25-59$ & 12 & $\begin{array}{c}\text { Kecemasan } \\
\text { sedang } \\
\text { Kecemasan } \\
\text { berat }\end{array}$ & $66 \%$ \\
3. & $60-74$ & 2 & Panik & - \\
4. & $75-80$ & - & & $100 \%$ \\
\hline
\end{tabular}

Tabel 4 Hasil Analisis Wawancara Mahasiswa

\begin{tabular}{|c|c|c|c|c|}
\hline \multirow[t]{2}{*}{ Pertanyaan } & \multirow{2}{*}{$\begin{array}{c}\text { Jumlah } \\
\text { Mahasis wa } \\
\text { yang } \\
\text { Menjawab } \\
\text { Sama }\end{array}$} & \multirow{2}{*}{$\begin{array}{c}\text { Jumlah } \\
\text { Mahas is wa yang } \\
\text { Tidak Menjawab } \\
\text { Sama }\end{array}$} & \multicolumn{2}{|c|}{$\begin{array}{c}\text { Persentase (\%) } \\
\text { Jawaban } \\
\text { Mahasiswa }\end{array}$} \\
\hline & & & Sama & $\begin{array}{l}\text { Tidak } \\
\text { Sama }\end{array}$ \\
\hline 1 & 0 & 18 & 0 & 100 \\
\hline 2 & 17 & 1 & 95 & 5 \\
\hline 3 & 4 & 14 & 22,23 & 77,77 \\
\hline 4 & 6 & 12 & 33,34 & 66,66 \\
\hline 5 & 16 & 2 & 88,88 & 11,12 \\
\hline 6 & 18 & 0 & 100 & 0 \\
\hline 7 & 14 & 4 & 77,77 & 22,23 \\
\hline 8 & 0 & 18 & 0 & 100 \\
\hline 9 & 0 & 18 & 0 & 100 \\
\hline 10 & 18 & 0 & 100 & 0 \\
\hline 11 & 16 & 2 & 88,88 & 11,12 \\
\hline 12 & 18 & 0 & 100 & 0 \\
\hline 13 & 18 & 0 & 100 & 0 \\
\hline 14 & 18 & 0 & 100 & 0 \\
\hline 15 & 18 & 0 & 100 & 0 \\
\hline 16 & 18 & 0 & 100 & 0 \\
\hline 17 & 18 & 0 & 100 & 0 \\
\hline 18 & 18 & 0 & 100 & 0 \\
\hline 19 & 17 & 1 & 95 & 5 \\
\hline 20 & 17 & 1 & 95 & 5 \\
\hline
\end{tabular}

Pengambilan data mengenai kecemasan mahasiswa dalam menghadapi seminar hasil skripsi di lingkungan FKIP Universitas Muhammadiyah Palembang menggunakan angket (kuesioner) dan wawancara. Kecemasan mahasiswa 
menghadapi seminar hasil skripsi dalam penelitian ini diukur melalui beberapa pertanyaan yang berkaitan dengan kecemasan dalam menghadapi seminar hasil ujian. Sesuai dengan tujuan penelitian yaitu: 1) Untuk mengetahui tingkat kecemasan mahasiswa dalam menghadapi seminar hasil skripsi di lingkungan FKIP Universitas Muhammadiyah Palembang; 2) Untuk mengetahui faktor-faktor yang berpengaruh terhadap kecemasan mahasiswa dalam menghadapi seminar hasil skripsi di lingkungan FKIP Universitas Muhammadiyah Palembang, maka dapat dijelaskan faktor-faktor apa saja yang berpengaruh terhadap kecemasan mahasiswa dalam menghadapi seminar hasil skripsi dilingkungan FKIP Universitas Muhammadiyah Palembang.

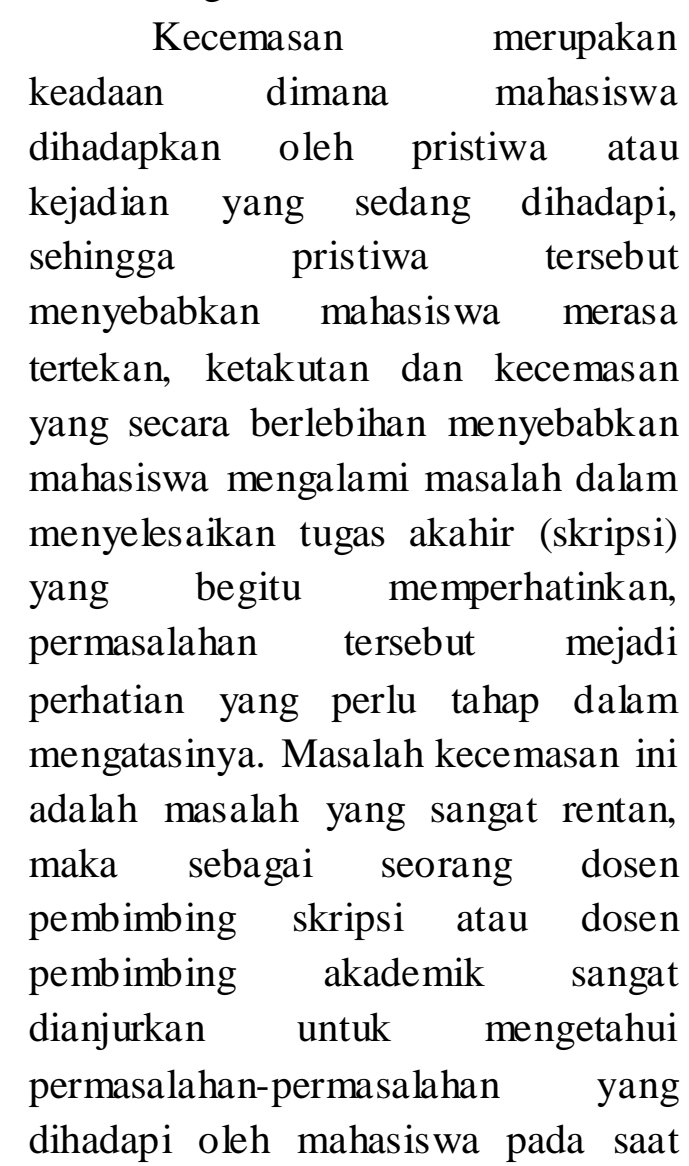

proses menyelesaikan skripsi. Kecemasan yang berlebihan adalah menjadi masalah yang besar yang akan dialami mahasiswa jika tidak segera diatasi, karena semakin tinggi tingkat kecemasan yang dimliki mahasiswa dalam menghadapi seminar hasil skripsi maka akan semakin lama mahasiswa memperoleh gelar sarjana.

Berdasarkan hasil penelitian yang telah dilakukan pada tanggal 31 Agustus 2018 dilingkungan FKIP Universitas Muhammadiyah Palembang, mahasiswa yang tidak mempunyai kecemasan dengan persentase sebesar 22,22\%, mahasiswa yang mempunyai tingkat kecemasan sedang dengan persentase sebesar $66,66 \%$ dan mahasiswa yang mempunyai tingkat kecemasan yang berat dengan persentase sebesar $11,11 \%$.

Kecemasan yang terjadi pada mahasiswa dalam menghadapi seminar hasil skripsi dilingkungan FKIP Universitas Muhammadiyah Palembang disebabkan oleh beberapa faktor. Faktor yang mempengaruhi kecemasan mahasiswa dalam menghadapi seminar hasil skripsi, yaitu:

1. Rasa percaya diri

Percaya diri merupakan keyakinan seseorang terhadap segala aspek kelebihan yang dimilikinya dan kenyataan tersebut membuatnya merasa mampu untuk bisa mencapai berbagai tujuan hidup. ndividu yang memiliki kepercayaan diri besar akan mengurangi kecemasan. Sebaliknya jika seorang individumemiliki 
kepercayaan diri yang rendah maka kecemasannya akan meningkat. Hal ini juga sesuai dengan teori yang ada pada bab 2 yang menjelaskan bahwa, seseorang yang mempunyai self efficacy yang tinggi akan mempunyai kemampuan untuk menyesuaikan diri lebih baik, lebih dapat mempengaruhi situasi dan dapat menggunakan kemampuan yang dimiliki dengan lebih baik, sehingga perasaan terancam dan tidak aman dapat dikendalikan.

2. Usia

Seseorang yang mempunyai usia lebih muda ternyata lebih mudah mengalami gangguan kecemasan dari pada seseorang yang lebih tua, tetapi ada juga yang berpendapat sebaliknya terhitung mulai saat dilahirkan sampai saat berulang tahun. Semakin cukup umur, tingkat kematangan dan kekuatan sesorang akan lebih matang dalam berfikir dan bekerja. Dari segi kepercayaan masyarakat seseorang yang lebih di percaya dari orang yang belum cukup tinggi kedewasaannya. Hal ini sebagai akibat dari pengalaman dan kematangan jiwanya. Usia menunjukkan ukuran waktu pertumbuhan dan perkembangan seorang individu.

3. Jenis kelamin

$\begin{array}{lr}\text { Perempuan lebih cemas } \\ \text { akan ketidakmampuannya } \\ \text { dibanding laki-laki. Laki-laki lebih } \\ \text { aktif, eksploratif, } & \text { sedangkan } \\ \text { perempuan lebih } & \text { sensitif. } \\ \text { Penelitian lain juga menunjukkan }\end{array}$

bahwa laki-laki lebih rileks dibanding perempuan. Menurut Kaplan dan Sadock perempuan mengalami gangguan anxietas dari pada laki-laki.

4. Pemahaman isi skripsi

Pemahaman isi skripsi yang minim akan berpengaruh pada saat melakukan seminar hasil skripsi. Mahasiswa yang kurang memahami isi skripsi biasanya akan menjadi cemas ketika akan menghadapi seminar hasil skripsi. Rasa cemas tersebut akan membuat mahasiswa menjadi gugup, takut dan kurang percaya diri.

5. Hubungan interaksi dosen penguji dan pembimbing

Hubungan interaksi juga ternyata merupakan salah satu faktor penyebab dalam menghadapi seminar hasil. Kurangnya hubungan interaksi ini, akan membuat mahasiswa takut untuk berbicara ketika pada saat ujian proposal, ujian seminar hasil, dan ujian skripsi serta pada saat proses bimbingan skripsi.

6. Dukungan sosial

Kondisi lingkungan sekitar dapat menyebabkan seseorang menjadi lebih kuat dalam menghadapi permasalahan, misalnya lingkungan pekerjaan atau lingkungan bergaul yang tidak memberikan cerita negatif tentang efek negatif suatu permasalahan menyebabkan seseorang lebih kuat dalam menghadapi permasalahan, dukungan sosial dapat berupa pemberian informasi, pemberian bantuan, tingkah laku maupun 
materi, yang didapat melalui hubungan sosial yang akrab yang membuat individu merasa diperhatikan, dicintai, dan bernilai sehingga mengurangi tingkat kecemasan.

Menurut Apollo dukungan sosial tinggi akan mengalami hal-hal positif dalam hidupnya, mempunyai self esteem yang tinggi dan self concept yang lebih baik, serta kecemasan yang lebih rendah. orang-orang ini juga memiliki pandangan yang optimis terhadap kehidupan dan pekerjaannya, karena yakin akan kemampuannya, dibanding orang yang rendah dukungan sosialnya.

7. Kemampuan dalam berkomunikasi

Kemampuan dalam berkomunikasi sangat penting ketika kita berada di depan publik. Menurut Lukmantoro (2017), menjelaskan bahwa ketidakmampuan mahasiswa untuk berbicara di depan publik, sebenarnya, adalah akibat ketidakbiasaan mereka untuk tampil di depan kelas. Penyelesaian untuk masalah ini adalah dengan melatih mahasiswa untuk berbicara di depan publik (kelas) dalam berbagai mata kuliah tertentu yang lebih bersifat praktis, seperti retorika atau mata kuliah lain yang mengandalkan serta menuntut mahasiswa untuk aktif berbicara.

Hal ini juga ditambahkan oleh Yulia, Afrianti dan Octaviani (2015), menjelaskan bahwa komunikasi interpersonal yang berhasil dapat tercapai bila kedua belah pihak baik mahasiswa maupun dosen pembimbing skripsi mempunyai kesamaan makna dalam menginterpretasikan makna pesan yang disampaikan dalam proses komunikasi. Komunikasi interpersonal yang berhasil menyebabkan adanya perasaan sedang yang dapat mendorong adanya sikap keterbukaan kedua belah pihak, sebaliknya bila komunikasi yang terjalin tidak berjalan dengan baik maka menyebabkan timbulnya perasaan tegang yang dapat menyebabkan ketidaknyamanan pada proses bimbingan skripsi antara mahasiswa dengan dosen pembimbing skripsi.

8. Pola pikir

Faktor pola $\begin{array}{r}\text { pikir } \\ \text { dapat }\end{array}$
ternayata juga
mempengaruhi
mahasiswa dalam menghadapi
seminar hasil skripsi. Faktor
Menurut Salkind (2008), Pola
pikir berpengaruh sangat kuat
pada emosi yang memunculkan
perilaku yang maladaptif. Jika
seseorang mengalami perasaan
dan perilaku yang tidak
diinginkan, penting untuk
mengidentifikasi pemikiran yang
menyebabkan perasaan atau
perilaku dan belajar bagaimana
cara mengganti pemikiran
tersebut dengan pikiran - pikiran
yang mengarah pada reaksi yang
lebih diinginkan.

Salah satu cara yang dapat digunakan untuk mengatasi pola pikir mahasiswa adalah dengan menggunakan teknik self affirmation, melalui teknik self 
affirmation, pola pikir irrasional diubah melalui afirmasi positif yang dibuat dan dinyatakan secara berulang-ulang pada diri sendiri. Peserta didik secara pribadi mampu untuk melakukan pernyataan atau afirmasi diri secara positif dalam mengatasi masalah yang dihadapinya. Hal ini juga sesuai dengan pendapat Sherman (2008), menjelaskan bahwa self affirmation berposisi sebagai teknik untuk mengembangkan wawasan individu yang mengalami kecemasan akademik, dimana ketika ia memiliki wawasan yang luas, ia akan memiliki informasi sebenarnya dan dapat melihat permasalahn dari berbagai sudut pandang, sehingga kecemasan akademisnya menurun. Para peneliti menggambarkan "bagaimana afirmasi diri tidak hanya mempengaruhi respon kognitif untuk informasi dan peristiwa yang mengancam individu, tetapi juga adaptasi fisiologis dan perilaku mereka yang sebenarnya".

Faktor-faktor yang timbul tersebut, akan berdampak ketika mahasiswa akan melakukan atau saat menghadapi seminar hasil skripsi, sehingga rasa cemas tersebut membuat mahasiswa menjadi tidak konsentrasi karena adanya rasa takut, rasa khawtir dan rasa gugup.

Untuk mengatasi beberapa faktor yang berpengaruh terhadap kecemasan mahasiswa dalam menghadapi seminar hasil skripsi, mahasiswa harus memiliki tingkat kepercayaan tinggi, memahami dan menguasai isi skripsi yang telah di tulis sebelum seminar hasil skripsi, menghilangkan rasa cemas, membangun hubungan yang baik kepada dosen pembimbing maupun dosen penguji skripsi, dan membiasakan diri untuk berkomunikasi di depan publik supaya tidak cemas.

Studi seputar upaya meningkatkan literasi masih terus digalakkan hingga sekarang. Itu karena akhir-akhir ini muncul gejala yang megindikasikan kian memudarnya budaya literasi di negara kita. Banyak kalangan: masyarakat, generasi muda, siswa, bahkan mahasiswa seolah memunggungi dan ingin berjarak dengan literasi.

UNESCO tahun 2012 merilis data minat baca penduduk di Indonesia hanya $0,001 \%$ dan rata-rata masyarakat membaca 27 halaman buku dalam setahun (Nafisah, 2014). Data survei World's Most Literate Nations pada tahun 2016, diketahui minat baca masyarakat Indonesia menempati peringkat ke 60 dari 61 negara yang disurvei. selanjutnya, data studi Programme for International Student Assessment pada tahun 2015 menunjukkan literasi di Indonesia menempati urutan ke - 69 dari 76 negara yang dinilai. Yang terakhir, hasil studi Progress in International Reading Literacy Study tahun 2011 menempatkan Indonesia berada pada peringkat nomor 41 dari 45 negara peserta. Skor rata-rata kemampuan membaca siswa Indonesia adalah 405, atau berada di bawah skor rata-rata siswa internasional sebesar 500 . Fakta-fakta tersebut menandakan bahwa proses pendidikan di Indonesia 
belum berhasil menyemai tradisi literasi (OECD. 2016).

\section{KESIMPULAN}

Berdasarkan hasil penelitian yang telah dilaksanakan di FKIP Universitas Muhammadiyah Palembang pada tanggal 31 Agustus 2018, maka dapat disimpulkan bahwa faktor yang mempengaruhi kecemasan mahasiswa dalam menghadapi seminar hasil skripsi, yaitu: rasa percaya diri, usia, jenis kelamin, pemahaman isi skripsi, hubungan interaksi dosen penguji dan pembimbing, dukungan sosial, kemampuan dalam berkomunikasi, dan pola pikir.

\section{DAFTAR RUJUKAN}

Aprianti Y Rahayu. 2013. Anak Usia $T K$ :

Menumbuhkan

Kepercayaan Diri Melalui

Kegiatan Bercerita. Jakarta. Indeks.

Darmono \& A. M. Hasan. 2005. Menyelesaikan Skripsi Dalam Satu Semester. Jakarta. Gramedia Widiasarana Indonesia

Djiwandono, S. T. E. W. 2005. Psikologi Pendidikan. Jakarta. Gramedia.

Hawari, D. 2006. Manajemen Stress Cemas dan Depresi. Edisi 2. Jakarta. Balai Penerbit FKUI.

Linayaningsih, F. 2007. Kecemasan pada Mahasiswa Fakultas Psikologi Universitas Katolik Soegijapranata dalam Mengerjakan. Skripsi. Semarang. Universitas Katolik Soegijapranata.
Lukmantoro, T. 2017. Tingkat Kecemasan Mahasiswa Dalam Lingkup Akademis. Skripsi. Semarang. Universitas Diponegoro.

Nafisah, A. 2014. Arti Penting Perpustakaan bagi Upaya Peningkatan Minat Caca Masyarakat. Libraria. Journal of Perpustakaan. 2 (2), 69-81.

Nevid, Jeffrey, S., Rathus, S. A. \& Greene, B. 2005. Psikologi Abnormal, Edisi kelima. Jakarta. Erlangga.

OECD. 2016. PISA 2015 Result in Focus.

https://www.oecd.org/pisa/pisa -2015- results-in-focus.pdf

Rachmat, H. W. 2009. Kecemasan Pada Mahasiswa Saat Menghadapi Ujian Skripsi ditinjau dari Kepercayaan Diri. Skripsi. Semarang. Jurusan Psikologi Unika.

Salkind, Neil, J. 2008. Encyclopedia of Educational Psychology. California. SAGE Publications Ltd.

Yulia, P. C., Afrianti, H. \& Octaviani, V. 2015. Pengaruh Kominkasi Interpersonal Mahasiswa dan Dosen Pembimbing Skripsi Terhadap Gejala Stress Mahasiswa Dalam Menyusun Skripsi. Jurnal Professional FIS UNIVED. 2 (1): 61-69. 